\title{
Protegrin-1 Inhibits Dengue NS2B-NS3 Serine Protease and Viral Replication in MK2 Cells
}

\author{
Hussin A. Rothan, ${ }^{1}$ Ammar Y. Abdulrahman,, ${ }^{1}$ Pottayil G. Sasikumer, ${ }^{2}$ Shatrah Othman, ${ }^{1}$ \\ Noorsaadah Abd Rahman, ${ }^{3}$ and Rohana Yusof ${ }^{1}$ \\ ${ }^{1}$ Department of Molecular Medicine, Faculty of Medicine, University of Malaya, 50603 Kuala Lumpur, Malaysia \\ ${ }^{2}$ Department of Chemistry, Aurigene Discovery Technologies, Hosur Road, Bangalore 560 100, India \\ ${ }^{3}$ Department of Chemistry, Faculty of Science, University of Malaya, 50603 Kuala Lumpur, Malaysia
}

Correspondence should be addressed to Hussin A. Rothan, molec.genetics@gmail.com

Received 11 July 2012; Revised 31 August 2012; Accepted 2 September 2012

Academic Editor: Bernd H. A. Rehm

Copyright ( 92012 Hussin A. Rothan et al. This is an open access article distributed under the Creative Commons Attribution License, which permits unrestricted use, distribution, and reproduction in any medium, provided the original work is properly cited.

Dengue diseases have an economic as well as social burden worldwide. In this study, the antiviral activity of protegrin-1 (PG-1, RGGRLCYCRRRFCVCVGR) peptide towards dengue NS2B-NS3pro and viral replication in Rhesus monkey kidney (MK2) cells was investigated. The peptide PG-1 was synthesized by solid-phase peptide synthesis, and disulphide bonds formation followed by peptide purification was confirmed by LC-MS and RPHPLC. Dengue NS2B-NS3pro was produced as a single-chain recombinant protein in E. coli. The NS2B-NS3pro assay was carried out by measuring the florescence emission of catalyzed substrate. Real-time PCR was used to evaluate the inhibition potential of PG-1 towards dengue serotype-2 (DENV-2) replication in MK2 cells. The results showed that PG-1 inhibited dengue NS2B-NS3pro at $\mathrm{IC}_{50}$ of $11.7 \mu \mathrm{M}$. The graded concentrations of PG-1 at nontoxic range were able to reduce viral replication significantly $(P<0.001)$ at 24,48 , and $72 \mathrm{hrs}$ after viral infection. However, the percentage of inhibition was significantly $(P<0.01)$ higher at $24 \mathrm{hrs}$ compared to 48 and $72 \mathrm{hrs}$. These data show promising therapeutic potential of PG-1 against dengue infection, hence it warrants further analysis and improvement of the peptide features as a prospective starting point for consideration in designing attractive dengue virus inhibitors.

\section{Introduction}

Dengue infection causes various clinical symptoms ranging from mild fever to severe hemorrhagic fever and dengue shock syndrome [1-3]. The virus uses host cell ribosomes to translate its genomic RNA to full-length precursor polyprotein. Subsequently, the host cell furin and dengue NS2BNS3 serine protease (NS2B-NS3pro) cleave viral polyprotein at various regions to produce structural and nonstructural viral proteins [4-6]. The NS3 protein is one of the viral nonstructural proteins that possess enzymatic activities. The Nterminal of this protein contains 180 amino acid residues that represent NS3 protease $[7,8]$, while C-terminal region contains amino acid residues that represent RNA helicase and RNA-stimulated NTPase $[9,10]$. The activity of NS2BNS3pro depends on the interaction with its cofactor NS2B to form a NS2B-NS3pro complex [11]. It has been found that the disruption of NS2B-NS3pro functions inhibits viral replication [12]. Therefore, NS2B-NS3pro is considered as a potential target for the design of antiviral drugs [13].

At present, a legitimate vaccine or treatment to prevent or to cure this disease is unavailable [14]. These facts emphasize the need for a better understanding of the mechanism of viral infection and propagation in the host cell to combat this disease. Recently, computational studies indicated that cationic cyclic peptides have potential inhibition towards dengue NS2B-NS3pro $[15,16]$. Protegrin-1 (PG-1, RGGRLCYCRRRFCVCVGR) is an eighteen amino acids cationic cyclic peptide with high content of basic residues and two disulphide bonds. The peptide is originally isolated from porcine white blood cells and considered as an antibiotic agent against a broad range of microorganisms $[17,18]$. The formation of two disulphide bonds between cysteine residues endows PG-1 with a stabile $\beta$-hairpin secondary structure 
that is crucial for antimicrobial activity $[19,20]$. Therefore, removal of these two disulphide bonds is found to noticeably reduce the antimicrobial activity of PG-1 [21]. The peptide is able to penetrate and disrupt the cell membrane by homodimerization $[22,23]$. The mechanism of this activity depends on the secondary structure and the cationic nature of PG-1 molecules which are essential to generate pores in the cell membrane of microorganism [24-27]. In this study, our objective was to examine the efficacy of PG-1 as cationic cyclic peptide to inhibit dengue serine protease and subsequently reduce viral replication in host cells.

\section{Methods}

2.1. Synthesis of Cyclic PG-1. The linear peptides were prepared by automated peptide synthesis using Symphony parallel synthesizer (Protein Technologies, Tucson, AZ, USA) by standard solid-phase peptide synthesis. The crude peptides were lyophilized before proceeding to folding experiments. The lyophilized peptide was dissolved in 20\% DMSO solution in a round bottom flask and stirred on a magnetic stirrer to produce a peptide concentration of $1.1 \mathrm{mM}$. The progress of the reaction was monitored by HPLC and LCMS. The formation of the first disulphide bond was completed within $24 \mathrm{hrs}$. The solution was then lyophilized to proceed for second disulfide formation. The lyophilized peptide with the first disulphide bond was dissolved in acetic acid water (4:1) so that the peptide concentration was $1.2 \mathrm{mM}$ and iodine (10 equivalents) was added in one portion. The reactions were stirred at $25^{\circ} \mathrm{C}$ for $60 \mathrm{~min}$ and then quenched by diluting with water and extracting with $\mathrm{CCl}_{4}$ to remove excess iodine. The aqueous phase was then lyophilized to give the crude peptide. The identity of the crude peptide was confirmed by LC-MS. Purification of crude cyclised peptide was accomplished by RP-HPLC (Agilent 1200 series). The identity of the purified peptide with $98 \%$ purity was confirmed by LC-MS (Shimadzu LC/MS 2020, single quad).

2.2. Production of NS2B-NS3pro in E. coli. To produce single chain protease NSB2- $\left(G_{4}-T-G_{4}\right)-N S 3$, the NS2B fragments were amplified individually by PCR using the primer pairs NS2B-F (5'-ATACTGAGGATCC GCCGATTTGGAACTG$\left.3^{\prime}\right)$ and NS2Blinker-R (ACCTACTAGGTACCTCCTCCACCCAGTGTCTGTTCTTC). The NS2B-NS3 was amplified by NS3linker-F (5'-ATCTATAGGTACCGGCGGTGGAGGTGCTGGAGTATTGTGG-3') and NS3-R $\left(5^{\prime}\right.$-AGCATAAGCTTAAGCTTCAATTTTCT- $\left.3^{\prime}\right)$. The linker sequence was added to NS2Blinker-R and NS3linker-F primers which included the site for KpnI restriction enzyme (all restriction sites are underlined). The PCR product of NS2B fragment was digested with BamHI and $K p n I$ while NS2B fragment was digested with KpnI and HindIII. Purified fragments were cloned into $\mathrm{pQE} 30$ plasmid downstream of $6 \times$ His tag. The Escherichia coli X-blue strain (Promega, USA) was transformed with pQE30- $c N S B-\left(G_{4} T G_{4}\right)-N S 3$ plasmid. The recombinant $E$. coli was inoculated in LuriaBertani liquid medium ( $1 \%$ tryptone, $1 \% \mathrm{NaCl}, 0.5 \%$ yeast extract, w/v, pH 7.0) supplemented with $100 \mathrm{mg} / \mathrm{L}$ ampicillin and cultured overnight at $37^{\circ} \mathrm{C}$. In brief, $10 \mathrm{ml}$ of overnight grown culture was added to $1000 \mathrm{~mL}$ of medium and incubated with shaking at $37^{\circ} \mathrm{C}$ until the optical density at $600 \mathrm{~nm}$ reached 0.5 . Subsequently, isopropylthio- $\beta$-Dgalactoside (IPTG) was then added to a final concentration of $0.5 \mathrm{mM}$ and the bacteria were cultured for an additional $5 \mathrm{hrs}$ at $37^{\circ} \mathrm{C}$ in a shaking incubator to induce protein expression. Finally, bacterial cells were harvested by centrifugation at $4000 \mathrm{rpm}$ for $15 \mathrm{~min}$ at $4^{\circ} \mathrm{C}$.

2.3. Protein Purification. The recombinant NS3pro was produced as soluble proteins and, therefore, the purification had been performed by His GraviTrap Flow precharged Ni Sepharose 6 Fast column (Amersham Biosciences, USA) according to the manufacturer's instructions. In brief, the column was normalized with phosphate buffer $(20 \mathrm{mM}$ sodium phosphate buffer and $500 \mathrm{mM} \mathrm{NaCl}, \mathrm{pH}$ 7.4). The sample was loaded into the column and the column was washed with binding buffer (phosphate buffer containing $20 \mathrm{mM}$ imidazole, $\mathrm{pH}$ 7.4). The recombinant protein was eluted with elution buffer (phosphate buffer containing $200 \mathrm{mM}$ imidazole, $\mathrm{pH}$ 7.4). Further purification was applied using gel affinity chromatography to achieve more than $95 \%$ purity.

2.4. Protease Assay. The bioassay used in this study was modified from the method published by Kiat and coworkers [28]. Reaction mixtures with total volume of $200 \mu \mathrm{L}$ were prepared. These reaction mixtures consisted of $100 \mu \mathrm{M}$ fluorogenic peptide substrate (Boc-Gly-Arg-Arg-MCA), $2 \mu \mathrm{M}$ NS2B-NS3pro complex, with or without PG-1 of varying concentrations, buffered at pH 8.5 with $200 \mathrm{mM}$ Tris$\mathrm{HCl}$. The PG-1 was initially prepared in Tris- $\mathrm{HCl}$ buffer and assayed at five different concentrations. The reaction mixtures without fluorogenic peptide substrate were firstly incubated at $37^{\circ} \mathrm{C}$ for 30 minutes. Subsequently, the substrate was added and the mixture was further incubated at the same temperature for 30 minutes. Triplicates were performed for all measurements and the readings were taken using Tecan Infinite M200 Pro fluorescence spectrophotometer. Substrate cleavage was optimized at the emission at $440 \mathrm{~nm}$ upon excitation at $350 \mathrm{~nm}$. The readings were then used for calculating $K_{m}$ values of peptide substrate and $\mathrm{IC}_{50}$ values of peptide inhibitors using nonlinear regression models in GraphPad Prism 5.01 software.

2.5. Maximum Nontoxic Dose Test (MNTD). The MK2 cell lines were seeded at $1 \times 10^{4}$ cells per well in triplicate at optimal conditions $\left(37^{\circ} \mathrm{C}, 5 \% \mathrm{CO}_{2}\right.$ in humidified incubator) in 96 well plates. PG-1 was diluted to serial concentrations $2.5,12.5,25,50,100$ and $200 \mu \mathrm{M}$ with DMEM media supplemented with $2 \%$ FBS. The cell culture was analyzed at 24 , 48 and 72 hours using nonradioactive cell proliferation assay (Promega, USA) according to the manufacture protocol.

2.6. Treatment of DENV-2-Infected Cells with PG-1 Peptide. The MK2 cell lines were grown in a 24-well tissue culture 


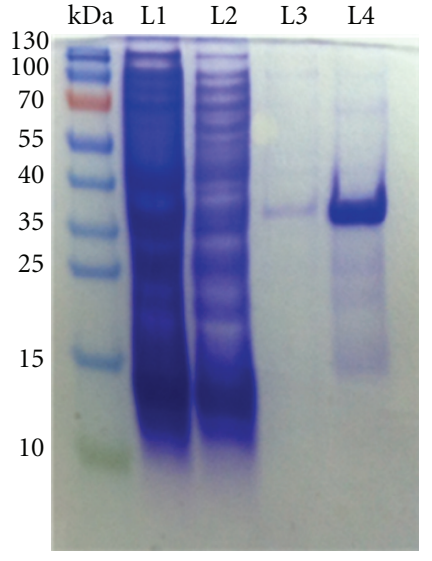

(a)

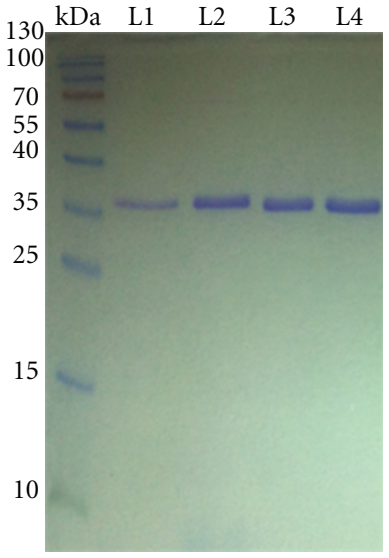

(b)

Figure 1: Production of single chain protease NSB2- $\left(G_{4}-T-G_{4}\right)-N S 3$ pro in E. coli. (a) The recombinant NS2B-NS3pro was produced as soluble proteins and purified by nickel column. L1: cell lysate, L2: washing flow through, L3: elution 1, and L4: elution 2. (b) Further purification was applied using gel affinity chromatography (95\% of enzyme purity) L1 to L4: Elution 1 to 4 . The activity of purified enzyme was assessed by catalyzing the fluorogenic peptide substrate (Boc-Gly-Arg-Arg-MCA).

plate $\left(1 \times 10^{5}\right.$ cells/well $)$, incubated 24 hrs under optimal conditions $\left(37^{\circ} \mathrm{C}\right.$ and $\left.5 \% \mathrm{CO}_{2}\right)$. DENV-2 was added to the wells (MOI of 2) followed by incubation for $1 \mathrm{hr}$ with gentle shaking every $10 \mathrm{~min}$ for optimal virus to cell contact. The virus supernatant was removed, and the cells were washed twice with fresh serum free DMEM media to remove residual virus. New complete DMEM media containing 2.5, 7.5 and $12.5 \mu \mathrm{M}$ of PG-1 were added and the cultures were incubated for 24, 48 and $72 \mathrm{hrs}$. Afterwards, cellular supernatants were collected and stored at $-80^{\circ} \mathrm{C}$ for viral quantification by realtime PCR.

2.7. Real-Time PCR. For quantification of DENV-2 copies, the standard curve was generated by 10 -fold serial dilution of known copies of DENV-2 RNA. Viral RNA was extracted from culture supernatant using QIAmp viral RNA minikit (QIAGEN, Germany) according to the manufacturer's instructions. A fragment located at the $5^{\prime}$ UTR region of the virus genome was used to generate the primers. One-step RT-PCR using SyBr Green Master Kit (Qiagen, Germany) was used to conduct absolute quantification using ABI7300 machine from Applied Biosystems (Foster City, $\mathrm{CA})$. The PCR programme included 1 cycle of $50^{\circ} \mathrm{C}$ for $2 \mathrm{~min}, 1$ cycle of $95^{\circ} \mathrm{C}$ for $10 \mathrm{~min}$, and 40 cycles of $95^{\circ} \mathrm{C}$ for $15 \mathrm{sec}$ and $60^{\circ} \mathrm{C}$ for $1 \mathrm{~min}$. Dissociation curve analysis was added to the end of each run. Results were analyzed using Sequence Detection Software Version 1.3 (Applied Biosystems, Foster City, CA, USA).

2.8. Statistical Analysis. All the assays were done in triplicates and the statistical analyses were performed using GraphPad Prism version 5.01 (GraphPad Software, San Diego, CA). $P$ values $<0.05$ were considered significant. Error bars are expressed as \pm SD.
TABle 1: The parameters of PG-1 Inhibition potential towards NS2B-NS3pro.

\begin{tabular}{lcc}
\hline Parameter* & Values & Std. Error \\
\hline$V_{\max }$ & $0.28 \mu \mathrm{mol} / \mathrm{min}$ & \pm 0.01 \\
Alpha & 3.14 & \pm 0.81 \\
$K_{i}$ & $5.85 \mu \mathrm{M}$ & \pm 1.82 \\
$\mathrm{IC}_{50}$ & $11.70 \mu \mathrm{M}$ & \pm 2.23 \\
$K_{m}$ & $109.10 \mu \mathrm{M}$ & \pm 7.50 \\
\hline
\end{tabular}

$* V_{\max }:$ maximum enzyme velocity $(\mu \mathrm{mol} / \mathrm{min}) . K_{m}$ : Michaelis-Menten constant $(\mu \mathrm{M}) . K_{i}$ : inhibition constant $(\mu \mathrm{M})$. Alpha: constant that determines mechanism. If alpha $=1$, this is the same as noncompetitive. If alpha is very high, then the model approaches a competitive model. If alpha is very low (but greater than zero), the model approaches an uncompetitive model. All parameters were calculated by GraphPad Prism 5.0 software.

\section{Results and Discussion}

The recombinant NS2B-NS3pro was produced as a soluble protein in E. coli and purified by nickel column (Figure 1(a)). Further purification was applied using gel affinity chromatography to achieve more than $95 \%$ of enzyme purity (Figure 1(b)). The activity of purified enzyme had been assessed at $37^{\circ} \mathrm{C}$ by catalyzing the fluorogenic peptide substrate t-Butyloxycarbonylglycyl-L-arginylL-arginyl-L-4-methylcoumaryl-7-amide (Boc-Gly-Arg-ArgMCA). The PG-1 peptide was added to the protease reaction at different concentrations and the inhibition profile was plotted as shown in Figure 2.

It was observed that the inhibition potential increased with PG-1 concentration and the highest inhibition (95.7\%) with low concentrations of PG-1 was at $40 \mu \mathrm{M}$. The kinetic assay study indicated that PG-1 competitively inhibited NS2B-NS3pro activity (alpha value 3.14) with $K_{i}$ value $5.85 \mu \mathrm{M}$ (Table 1). Intriguingly, the maximum enzyme velocity decreased threefold when PG-1 concentration was $20 \mu \mathrm{M}$ 


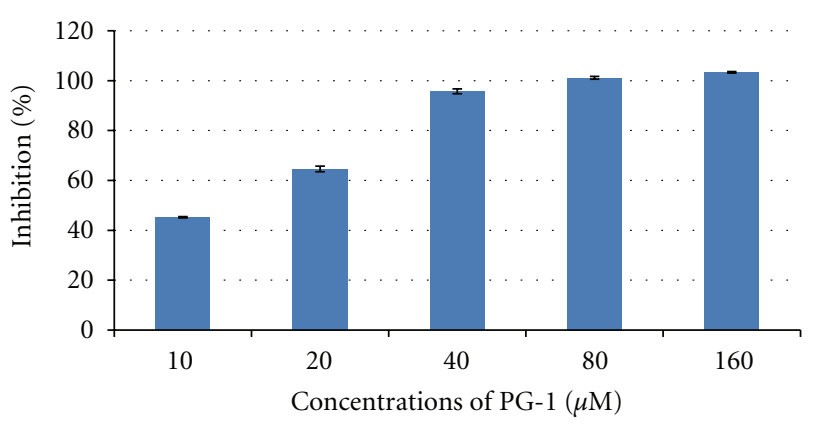

Figure 2: Dengue protease inhibition assay. The reaction mixtures consisted of fluorogenic peptide substrate and NS2B-NS3pro, with or without PG-1 of varying concentrations. The PG-1 was initially prepared in Tris- $\mathrm{HCl}$ buffer and assayed at five different concentrations, $10-160 \mu \mathrm{M}$. The best inhibition with low concentration of PG1 was observed at $40 \mu \mathrm{M}$ with $95.7 \%$ inhibition.

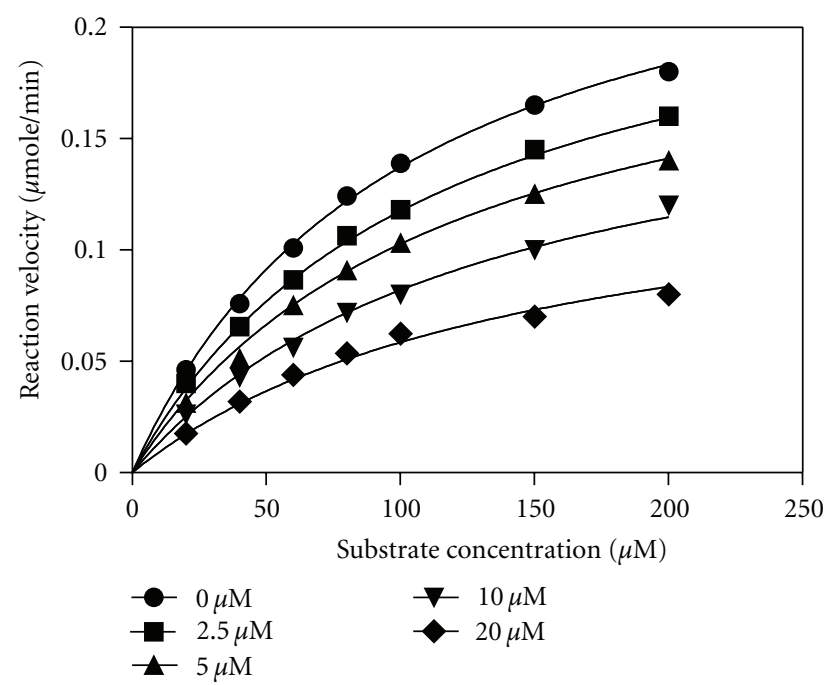

FIGURE 3: Kinetic assay plot for the inhibition of the NS2B-NS3pro from dengue virus by PG-1 peptide. This assay was carried out using increasing concentration of inhibitor while all other conditions were kept constant. The data was analysed by Michaelis-Menten model under nonlinear regression curve fit in GraphPad Prism 5 software. The peptide concentrations were $0,2.5,5,10$, and $20 \mu \mathrm{M}$. The maximum enzyme velocity decreased from approximately threefold when PG-1 concentration was $20 \mu \mathrm{M}$.

(Figure 3). Previous studies have shown that various types of natural and chemical compounds were able to inhibit dengue NS2B-NS3pro activity. For example, some of plant natural compounds, such as Chalcones, have shown good inhibition potential against the dengue protease ( $K_{i}$ value $\left.21-25 \mu \mathrm{M}\right)$ [28]. The synthesized peptidic $\alpha$-keto-amide compound inhibited dengue NS2B-NS3pro with $K_{i}$ value of $47 \mu \mathrm{M}$ [29]. Most recent study indicated that the retrotripeptides with an arylcyanoacrylamide group as N-terminal cap exhibited high inhibition potential against dengue protease with $K_{i}$ value of $4.6 \mu \mathrm{M}$ [30]. Most recent study showed that the inhibition potential of some chemical compounds towards NS2B-NS3pro measured by $\mathrm{IC}_{50}$ was $15.4,20.4$, and $27.0 \mu \mathrm{M}$ [31].

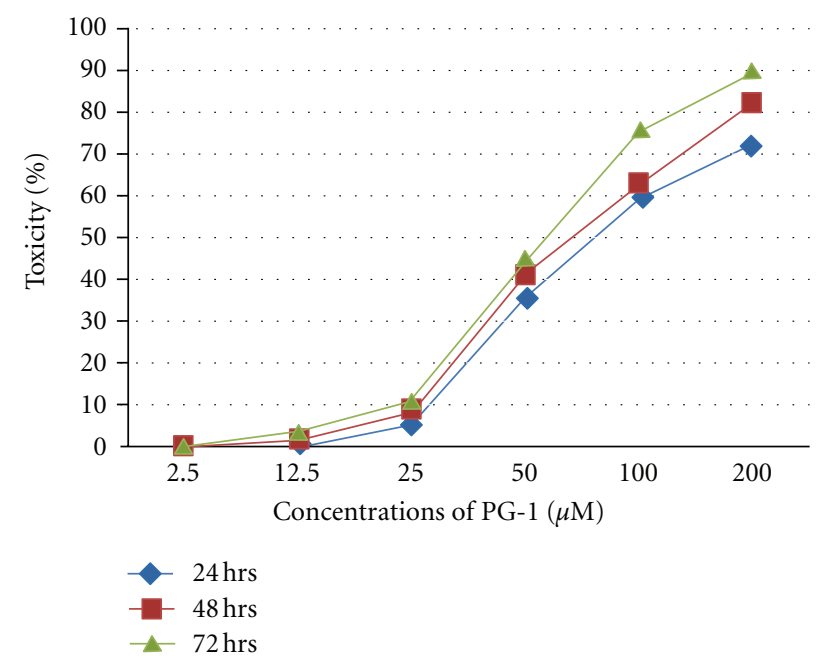

Figure 4: Maximum nontoxic dose (MNTD) of PG-1.The MK2 cell lines were seeded at $1 \times 10^{4}$ cells per well in triplicate at optimal conditions $\left(37^{\circ} \mathrm{C}, 5 \% \mathrm{CO}_{2}\right.$ in humidified incubator) in 96 well plates. PG-1 was diluted to serial concentrations $2.5,12.5,25,50$, 100 , and $200 \mu \mathrm{M}$ with DMEM media supplemented with $2 \%$ FBS. The cell culture was analyzed at 24,48 , and $72 \mathrm{hrs}$ using NonRadioactive Cell Proliferation assay (Promega, USA) according to the manufacture protocol. The toxic dose of MK2 cells was identified to be greater than $12.5 \mu \mathrm{M}$.

Cytotoxicity and compound stability can be considered as major limitations of the practical application of protease inhibitors. In this study, to test PG-1 toxicity, MK2 cell lines were incubated with increasing concentrations of PG1 for 24,48 , and 72 hrs. The PG-1 peptide showed toxic effect against MK2 cell lines at concentrations greater than $12.5 \mu \mathrm{M}$ (Figure 4). Other studies indicated that PG-1 was also toxic to $293 \mathrm{~A}$ cell lines (human embryonic kidney cells) at $50 \mu \mathrm{g} / \mathrm{ml}(25 \mu \mathrm{M})$ [32] and more than $50 \%$ of human red blood cells lyses were observed at $80 \mu \mathrm{g} / \mathrm{ml}(40 \mu \mathrm{M})$ [33]. Therefore, three concentrations at nontoxic range were used to test PG-1 stability and ability to reduce dengue viral replication in MK2 cell lines. The results showed that the viral copy number significantly $(P<0.001)$ reduced with increasing concentrations of PG-1 (Figure 5(a)). Furthermore, the highest inhibition percentage was observed when the PG- 1 concentration was $12.5 \mu \mathrm{M}$ at 24,48 and $72 \mathrm{hrs}$ (Figure 5(b)). However, the low concentrations exhibited less inhibition percentage at 48 and $72 \mathrm{hrs}$ as compared with $24 \mathrm{hrs}$, indicating that the PG-1 stability declined with longer incubation in culture media (Figures 5(a) and 5(b)). Similarly, it has been showed that at low doses $(4 \mu \mathrm{g} / \mathrm{ml})$, PG-1 has significant in vitro antimicrobial activity with low in vivo toxicity (up to $8 \mathrm{mg} / \mathrm{kg}$ i.v. mouse injection) [34]. This may be accounted by its short half-life in vivo as its level in mice plasma that was injected with $4 \mathrm{mg} / \mathrm{ml}$ i.v. declined rapidly to $28 \mu \mathrm{g} / \mathrm{ml}$ after $5 \mathrm{~min}$ [34]. Although PG-1 showed significant inhibition profile towards dengue virus in this study and to human immunodeficiency virus 1 (HIV1) in another study [35], the peptide instability should be considered as a major concern. The results in this study may give a clear picture that would then help in engineering new 


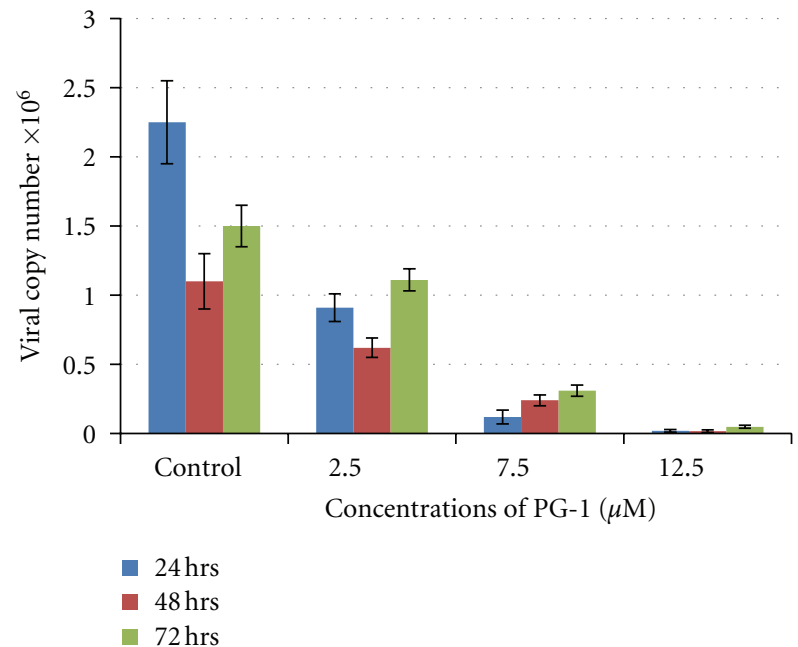

(a)

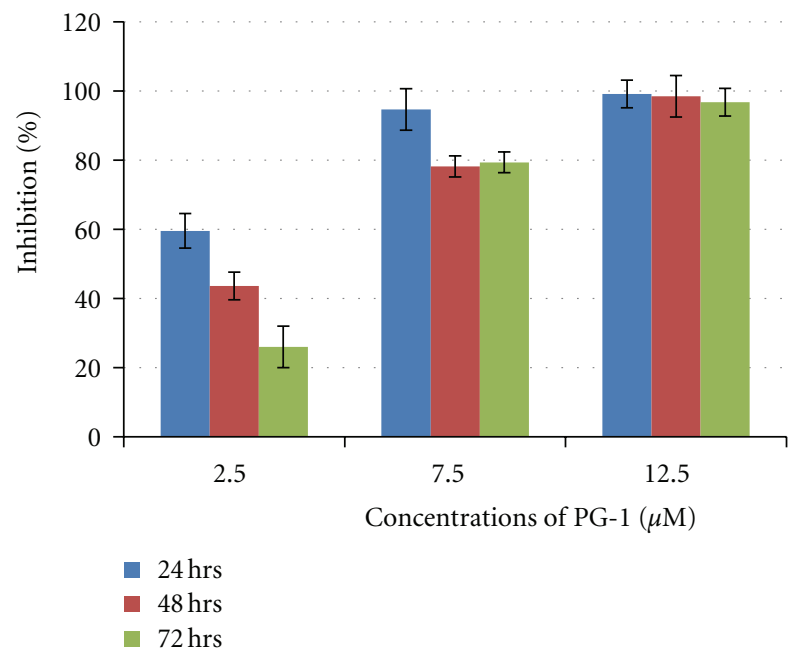

(b)

FIGURE 5: RNA quantification and the percentage of inhibition after applying different concentrations of PG-1 on MK2 cell lines infected with dengue virus. The standard curve was generated by 10 -fold serial dilution of known copies of dengue RNA. Viral RNA was extracted from cellular supernatant and the fragment located at the 5'UTR region of the virus genome was amplified using one-step RT-PCR. Significant reduction $(P<0.001)$ in viral copy number was observed with increasing PG-1 concentration $(\mathrm{a})$. The highest inhibition percentage was observed with $12.5 \mu \mathrm{M}$ at 24,48 , and $72 \mathrm{hrs}(\mathrm{b})$. PG-1 significantly $(P<0.01)$ inhibited DENV-2 replication in a dosedependent manner with the greatest inhibition effects at 24 hrs (two-way ANOVA with Bonferroni posttest, mean $\pm \mathrm{SD}$ ).

sequence of peptides to retain the antiviral activity against dengue while increasing its stability and eliminating the toxic characteristics of PG-1.

\section{Abbreviations}

PG-1:

Protegrin-1

(RGGRLCYCRRRFCVCVGR)

NS2B: $\quad$ NS2B cofactor amino acids sequence 49-95 in DEN2 NS2B and 1394-1440 in DENV-2 polyprotein

NS3: $\quad$ NS3 protease amino acids sequence $1-185$ in NS3 protease and $1476-1660$ in DENV-2 polyprotein

DENV-2: $\quad$ Dengue virus serotype 2

NS2B-NS3pro: NS2B fused to NS3 via 9 amino acids (G4-T-G4)

MCA: $\quad$ fluorogenic peptide substrate (Boc-Gly-Arg-Arg-AMC)

MK2 cells: Rhesus monkey kidney cell lines.

\section{Conflict of Interests}

The authors have declared that no competing interests exist.

\section{Acknowledgment}

This project was funded by the University of Malaya and Ministry of Science, Technology and Innovation (IPharm Grant 53-02-03-1049).

\section{References}

[1] J. G. Rigau-Pérez, G. G. Clark, D. J. Gubler, P. Reiter, E. J. Sanders, and A. V. Vorndam, "Dengue and dengue haemorrhagic fever," The Lancet, vol. 352, no. 9132, pp. 971977, 1998.

[2] T. P. Monath, "Dengue: the risk to developed and developing countries," Proceedings of the National Academy of Sciences of the United States of America, vol. 91, no. 7, pp. 2395-2400, 1994.

[3] D. J. Gubler and G. G. Clark, "Dengue/dengue hemorrhagic fever: the emergence of a global health problem," Emerging Infectious Diseases, vol. 1, no. 2, pp. 55-57, 1995.

[4] C. Lin, S. M. Amberg, T. J. Chambers, and C. M. Rice, "Cleavage at a novel site in the NS4A region by the yellow fever virus NS2B-3 proteinase is a prerequisite for processing at the downstream 4A/4B signalase site," Journal of Virology, vol. 67, no. 4, pp. 2327-2335, 1993.

[5] C. F. Arias, F. Preugschat, and J. H. Strass, "Dengue 2 virus NS2B and NS3 form a stable complex that can cleave NS3 within the helicase domain," Virology, vol. 193, no. 2, pp. 888899, 1993.

[6] M. Lobigs, "Flavivirus premembrane protein cleavage and spike heterodimer secretion require the function of the viral proteinase NS3," Proceedings of the National Academy of Sciences of the United States of America, vol. 90, no. 13, pp. 6218-6222, 1993.

[7] T. J. Chambers, C. S. Hahn, R. Galler, and C. M. Rice, "Flavivirus genome organization, expression, and replication," Annual Review of Microbiology, vol. 44, pp. 649-688, 1990.

[8] B. Falgout, M. Pethel, Y. M. Zhang, and C. J. Lai, "Both nonstructural proteins NS2B and NS3 are required for the proteolytic processing of dengue virus nonstructural proteins," Journal of Virology, vol. 65, no. 5, pp. 2467-2475, 1991. 
[9] A. E. Gorbalenya, E. V. Koonin, A. P. Donchenko, and V. M. Blinov, "Two related superfamilies of putative helicases involved in replication, recombination, repair and expression of DNA and RNA genomes," Nucleic Acids Research, vol. 17, no. 12 , pp. 4713-4730, 1989.

[10] G. Wengler and G. Wengler, "The NS3 nonstructural protein of flaviviruses contains an RNA triphosphatase activity," Virology, vol. 197, no. 1, pp. 265-273, 1993.

[11] R. Yusof, S. Clum, M. Wetzel, H. M. K. Murthy, and R. Padmanabhan, "Purified NS2B/NS3 serine protease of dengue virus type 2 exhibits cofactor NS2B dependence for cleavage of substrates with dibasic amino acids in vitro," The Journal of Biological Chemistry, vol. 275, no. 14, pp. 9963-9969, 2000.

[12] B. J. Geiss, H. Stahla, A. M. Hannah, H. H. Gari, and S. M. Keenan, "Focus on flaviviruses: current and future drug targets," Future Medicinal Chemistry, vol. 1, no. 2, pp. 327-344, 2009.

[13] S. M. Tomlinson, R. D. Malmstrom, and S. J. Watowich, "New approaches to structure-based discovery of Dengue protease inhibitors," Infectious Disorders—Drug Targets, vol. 9, no. 3, pp. 327-343, 2009.

[14] B. E. E. Martina, P. Koraka, and A. D. M. E. Osterhaus, "Dengue virus pathogenesis: an integrated view," Clinical Microbiology Reviews, vol. 22, no. 4, pp. 564-581, 2009.

[15] U. S. Tambunan and S. Alamudi, "Designing cyclic peptide inhibitor of dengue virus NS3-NS2B protease by using molecular docking approach," Bioinformation, vol. 5, pp. 250254, 2010

[16] U. S. F. Tambunan, N. Apriyanti, A. A. Parikesit, W. Chua, and K. Wuryani, "Computational design of disulfide cyclic peptide as potential inhibitor of complex NS2B-NS3 dengue virus protease," African Journal of Biotechnology, vol. 10, no. 57, pp. 12281-12290, 2011.

[17] V. N. Kokryakov, S. S. L. Harwig, E. A. Panyutich et al., "Protegrins: leukocyte antimicrobial peptides that combine features of corticostatic defensins and tachyplesins," FEBS Letters, vol. 327, no. 2, pp. 231-236, 1993.

[18] K. T. Miyasaki and R. I. Lehrer, " $\beta$-sheet antibiotic peptides as potential dental therapeutics," International Journal of Antimicrobial Agents, vol. 9, no. 4, pp. 269-280, 1998.

[19] R. L. Fahrner, T. Dieckmann, S. S. L. Harwig, R. I. Lehrer, D. Eisenberg, and J. Feigon, "Solution structure of protegrin1, a broad-spectrum antimicrobial peptide from porcine leukocytes," Chemistry and Biology, vol. 3, no. 7, pp. 543-550, 1996.

[20] J. R. Lai, B. R. Huck, B. Weisblum, and S. H. Gellman, "Design of non-cysteine-containing antimicrobial $\beta$-hairpins: structure-activity relationship studies with linear protegrin1 analogues," Biochemistry, vol. 41, no. 42, pp. 12835-12842, 2002.

[21] S. S. L. Harwig, "Intramolecular disulfide bonds enhance the antimicrobial and lytic activities of protegrins at physiological sodium chloride concentrations," European Journal of Biochemistry, vol. 240, no. 2, pp. 352-357, 1996.

[22] R. G. Panchal, M. L. Smart, D. N. Bowser, D. A. Williams, and S. Petrou, "Pore-forming proteins and their application in biotechnology," Current Pharmaceutical Biotechnology, vol. 3, no. 2, pp. 99-115, 2002.

[23] Y. Sokolov, T. Mirzabekov, D. W. Martin, R. I. Lehrer, and B. L. Kagan, "Membrane channel formation by antimicrobial protegrins," Biochimica et Biophysica Acta, vol. 1420, no. 1-2, pp. 23-29, 1999.

[24] G. Drin and J. Temsamani, "Translocation of protegrin I through phospholipid membranes: role of peptide folding,"
Biochimica et Biophysica Acta, vol. 1559, no. 2, pp. 160-170, 2002.

[25] D. Gidalevitz, Y. Ishitsuka, A. S. Muresan et al., "Interaction of antimicrobial peptide protegrin with biomembranes," Proceedings of the National Academy of Sciences of the United States of America, vol. 100, no. 11, pp. 6302-6307, 2003.

[26] N. Sitaram and R. Nagaraj, "Interaction of antimicrobial peptides with biological and model membranes: structural and charge requirements for activity," Biochimica et Biophysica Acta, vol. 1462, no. 1-2, pp. 29-54, 1999.

[27] R. E. W. Hancock and R. Lehrer, "Cationic peptides: a new source of antibiotics," Trends in Biotechnology, vol. 16, no. 2, pp. 82-88, 1998.

[28] T. S. Kiat, R. Pippen, R. Yusof, H. Ibrahim, N. Khalid, and N. A. Rahman, "Inhibitory activity of cyclohexenyl chalcone derivatives and flavonoids of fingerroot, Boesenbergia rotunda (L.), towards dengue-2 virus NS3 protease," Bioorganic and Medicinal Chemistry Letters, vol. 16, no. 12, pp. 3337-3340, 2006.

[29] Z. Yin, S. J. Patel, W. L. Wang et al., "Peptide inhibitors of dengue virus NS3 protease. Part 2: SAR study of tetrapeptide aldehyde inhibitors," Bioorganic and Medicinal Chemistry Letters, vol. 16, no. 1, pp. 40-43, 2006.

[30] C. Nitsche, M. A. M. Behnam, C. Steuer, and C. D. Klein, "Retro peptide-hybrids as selective inhibitors of the Dengue virus NS2B-NS3 protease," Antiviral Research, vol. 94, no. 1, pp. 72-79, 2012.

[31] C. C. Yang, Y. C. Hsieh, S. J. Lee et al., "Novel dengue virusspecific NS2B/NS3 protease inhibitor, BP2109, discovered by a high-throughput screening assay," Antimicrobial Agents and Chemotherapy, vol. 55, no. 1, pp. 229-238, 2011.

[32] L. Steinstraesser, B. Tippler, J. Mertens et al., "Inhibition of early steps in the lentiviral replication cycle by cathelicidin host defense peptides," Retrovirology, vol. 2, article 2, 2005.

[33] A. A. Langham, H. Khandelia, and Y. N. Kaznessis, "How can a $\beta$-sheet peptide be both a potent antimicrobial and harmfully toxic? Molecular dynamics simulations of protegrin-1 in micelles," Peptide Science, vol. 84, no. 2, pp. 219-231, 2006.

[34] D. A. Steinberg, M. A. Hurst, C. A. Fujii et al., "Protegrin-1: a broad-spectrum, rapidly microbicidal peptide with in vivo activity," Antimicrobial Agents and Chemotherapy, vol. 41, no. 8, pp. 1738-1742, 1997.

[35] H. Tamamura, T. Murakami, S. Horiuchi et al., "Synthesis of protegrin-related peptides and their antibacterial and anti-human immunodeficiency virus activity," Chemical and Pharmaceutical Bulletin, vol. 43, no. 5, pp. 853-858, 1995. 

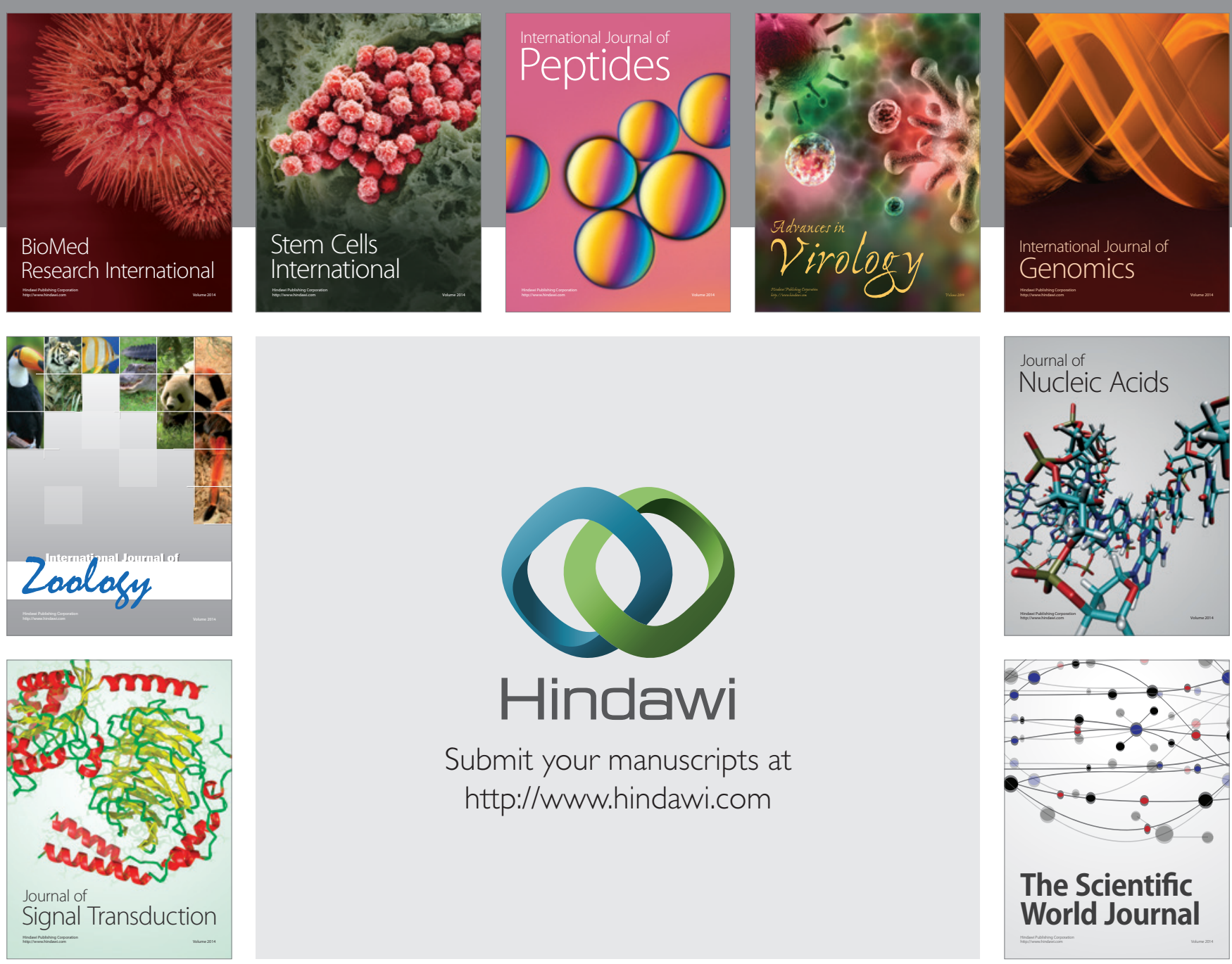

Submit your manuscripts at

http://www.hindawi.com
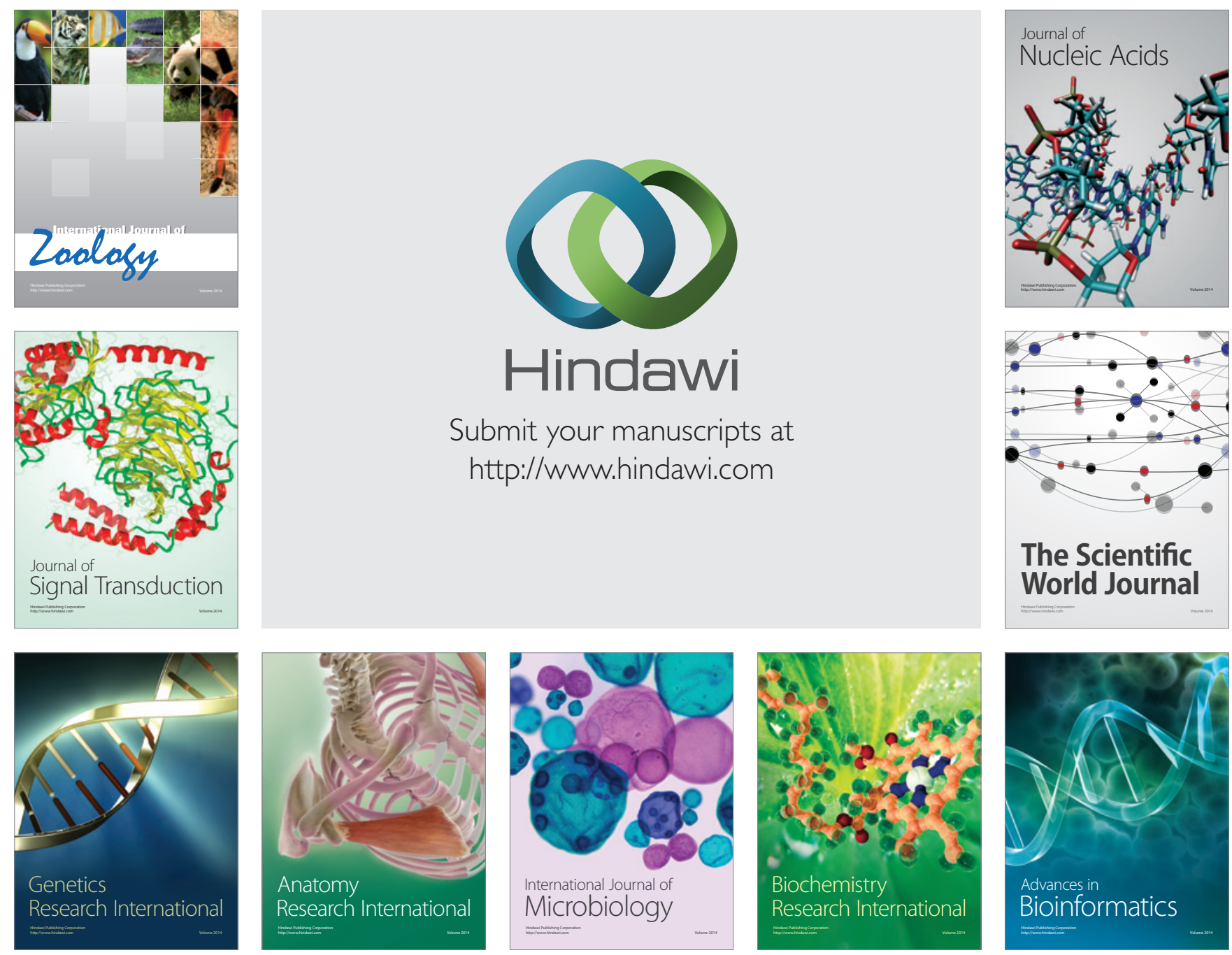

The Scientific World Journal
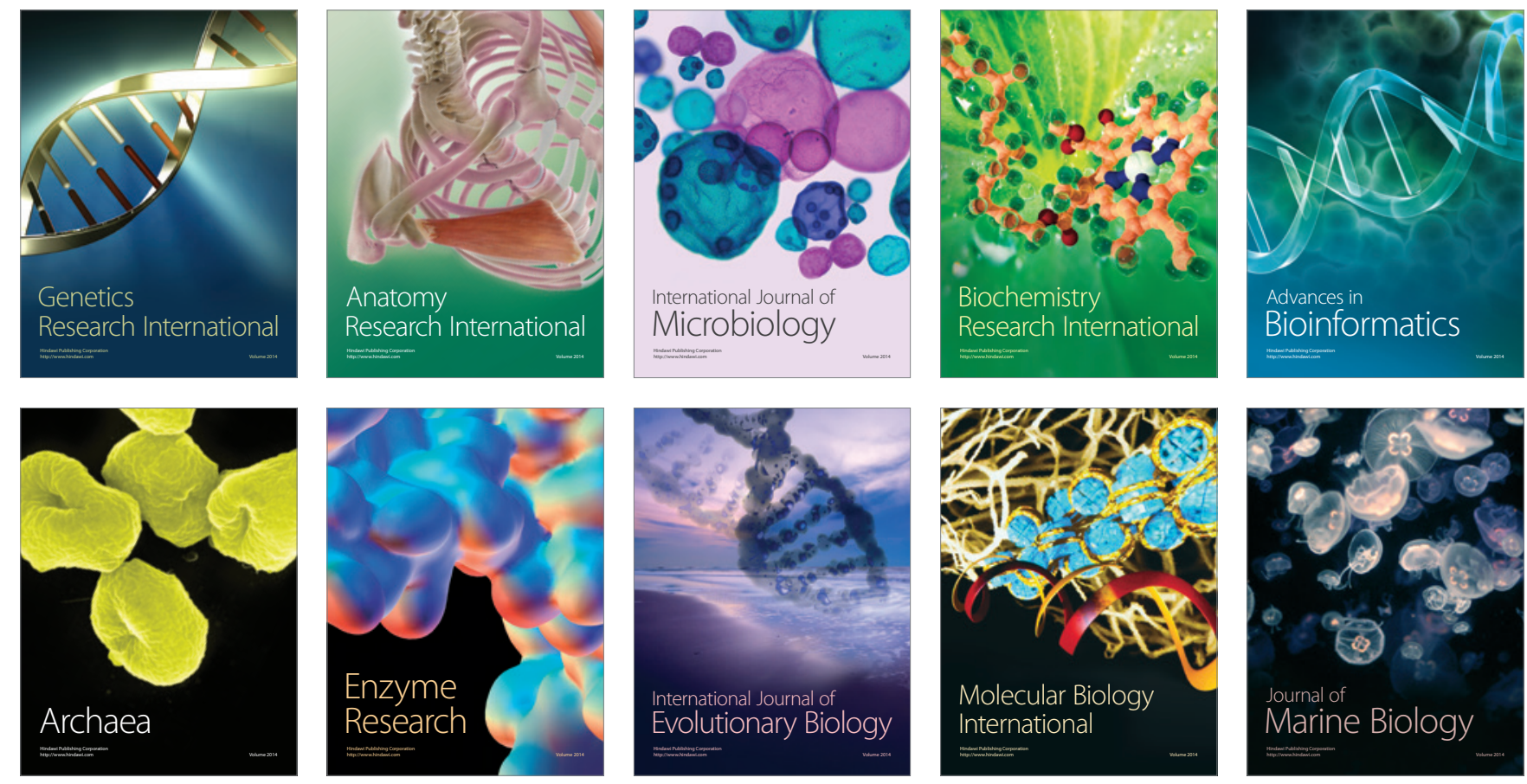